\title{
Coastal Environmental Change and the Salt Farmer Marginalization in Kusamba, Bali
}

\author{
Mujiburrahman*, Yety Rochwulaningsih, Singgih Tri Sulistiyono, Mahendra Pudji Utama \\ Department of History, Faculty of Humanities, Diponegoro University
}

\begin{abstract}
The coastal environment in Klungkung Regency is undergoing rapid change as a result of the pace of development to serve the demands of the tourism industry, especially in the Nusa Penida islands, which has been designated as a Strategic Tourism Area. Changes in the coastal environment has led to the marginalization of some coastal residents, especially palung salt farmers on the Kusamba beach. This traditional salt production technology highly depends on the stability of the coastal environment, especially the availability of land on the coast. The development of community ports on the Kusamba coast and surrounding areas to support tourism development easily creates pressure for palung salt farmers. This is because the entire production process in the traditional salt is carried out on the coastline. By relying on literature studies and documents as well as experience doing fieldwork in the Kusamba pesisri, this article shows that the development of the people's port and the arrangement of the Kusamba coastal area has marginalized palung salt farmers. Marginalization that can be identified includes restrictions on access to land on the coast border, leading to increasingly limited production areas.
\end{abstract}

Keywords: Tourism; Marginalization; Palung Salt; Kusamba; Bali.

\section{Introduction}

The tourism industry has become the most important contributor to Bali's economy. Tourism activities in the province have spread evenly to other regions and is no longer concentrated in southern Bali. One area that is rapidly developing as a tourist destination is Nusa Penida in eastern Bali. This area is an archipelago that includes the islands of Nusa Penida, Nusa Ceningan and Nusa Lembongan; and is part of Klungkung Regency called Nusa Penida district. This district is also called "Klungkung Islands", while the other three Banjarangkan district, Klungkung and Dawan are called "Klungkung Mainland". The larger areas of Klungkung Regency are connected by the Badung Strait.

Nusa Penida district has the highest level of poverty in Klungkung Regency. As of 2016, the number of poor people there stood at 5,668 people or 34.19 percent of the population.

\footnotetext{
* Corresponding author: mujiburrahman@students.undip.ac.id
} 
Poverty has been linked to arid and barren land, steep and rocky terrain, low rainfall, limited food crops and lack of rice of production, and relative isolation due to limited accessibility [1]. However, the exotic nature of Nusa Penida has become a major attraction for tourists. Tourist arrivals in the islands are higher than in Klungkung mainland. In 2017, the number of tourists coming to the Nusa Penida region reached 292,734, double the number in main tourist attractions in the Klungkung mainland - Kerta Gosa 53,322, Goa Lawah 72,472, and Levi Rafting 5,098 [2].

The Klungkung Regency Government has an ambition to make the Nusa Penida islands a mainstay tourist area to improve regional revenue and the economy of the local population. These efforts started with the development of people's ports in both the Klungkung mainland and Klungkung Islands. Since 2018, there have been more developments including the construction of the "Golden Triangle Port" to strengthen the connectivity of the two regions. The development of tourism in the coastal area along with supporting facilities and infrastructure has not only led to more income, prosperity and employment opportunities, but also changed the coastal environment that could end up marginalizing some people whose livelihoods depend on the use of resources in that environment. Marginalization in this case refers to the process that forces certain groups of people to be sidelined or powerless. Marginalization also involves perceptions about the conditions. A person or group of people who are marginalized feel excluded from and therefore also feel that they are not valuable members of society, unable to make valuable contributions to society, unable to access various services and/or open opportunities, and not given the opportunity to develop themselves as well as experience social exclusion from cultivated land [3].

Marginalization of coastal communities can occur in various forms, such as restrictions or even termination of access to the coastline through claims of ownership by tourism entrepreneurs on the grounds for the convenience of tourists. Cases of privatization of coastal borders in Bali occur, among others, in the Nusa Dua area, especially in the area of the Indonesia Tourism Development Corporation (ITDC) and Tanjung Benoa, Seminyak-Kuta, Bukit Unggasan, and Canggu (Badung Regency); Sanur - South Denpasar (Denpasar City), and Candi Dasa (Karangasem Regency). The privatization of borders for the sake of tourism has restricted or entirely prevent the general public and local communities from taking part in recreation or carrying out religious rituals and other activities freely on the beach [4]. Another form of marginalization of coastal communities is the limitation of access to the use of cultivated land in their environment. This has happened among seaweed farmers in Toyapakeh, Nusa Penida. They can no longer work freely as the coastal waters that serve as a seaweed cultivation area are used for marine tourism attractions [5].

Other coastal community groups that are actually vulnerable to experiencing obstacles in sustaining their livelihoods due to changes in the coastal environment in Klungkung Regency are salt farmers. This group is located on the Kusamba beach, Kecamatan Dawan. Kusamba is the only salt producing area in Klungkung Regency. Salt farmers in this area have unique production technology that has been passed down from generation to generation without undergoing substantial changes. They process sea water using the beach's black sand as a medium and evaporate it using a palung. This traditional salt production technology makes them highly dependent on the stability of the beach and the coastal environment. In this regard, this paper will discuss changes in the Klungkung coastal environment and their impact on the marginalization of Kusamba salt farmers. 


\section{Method}

This article is based on literature study and documents. Library materials used include research on traditional salt farming both in Bali and Java. To get information on the latest developments in traditional salt-making in Bali, online news stories were also used. Documents used in this article cover government publications which are used as a basis for the development and restructuring of coastal areas in Klungkung Regency. Some of the data used in this article were also obtained through fieldwork in the Kusamba salt-farming area conducted in 2012 and later in 2018 and 2019. Data and information obtained from various sources were then selected and organized according to the issues discussed.

\section{Result and Discussions}

\subsection{Traditional salt production in Kusamba}

The salt farmers in Kusamba begin their work in the morning. They start the day by making a medium for bittern, leveling the beach sand and pouring it with sea water taken directly from the sea with containers carried on the shoulder. The distance between the sand fields and the sea varies between 15-25 meters. It takes about 20 times the taking of water to flush all the sand. The sand that has been watered and dried forms sandflakes, which are then collected and transferred into a sandbox called belong bias. This medium sand must be poured again with sea water which is also taken by means of carrying it on the shoulder. As a resul of the watering, salty water will flow from the belong bias through a small pipe underneath it, and it is placed in a container called belong yeh. This filtering process is repeated up to three times to get saltwater ready to be evaporated inside the palung. In Kusamba, each palung is covered with coconut leaves. This distinguishes it from the palung in Tejakula Buleleng and in Amed Karangasem, where it is left open. Salt can start being removed from the palung in the afternoon if the weather allows, when the sun is scorching hot. If the weather is not too good or a bit cloudy, the evaporation process takes longer, up to three days. Freshly harvested salt must be drained in advance to reduce its water content.

Most of the equipment used in the process of making palung salt is made from natural materials, and a small portion is made using recycled materials. There are at least 16 types of equipment used in the salt-making process in Kusamba - penyodohan, tulud, penyacahan, penyaupan, penyuunan, timba, teku-teku, pemampangan, belong bias, belong yeh, kau, palung, tekep, sinduk, kukusan, and lekeh.

Penyodohan is a shovel made from coconut wood and used to take wet sand that has been used to filter sea water in belong bias. Tulud is made from coconut wood boards that are given long stems so that they resemble the letter T. This tool is used to flatten the surface of the sand on the beach before being showered with sea water. Penyacahan has a shape like a tulud, but the wooden boards have bamboo blades resembling a comb that serves to peel or separate dry sand flakes from the sand underneath. These sand flakes are then collected and put into a container called penyuunan. Panyaupan is made of two rectangular wooden planks, while penyuunan is made of bamboo weaving in the form of a half-ball. This container is used to transport dry flat sand from the beach to belong bias. Women salt farmers usually carry this container over their heads (Balinese: suun). Other equipment is a timba (bucket) used to transport sea water. The timba is made from used car tubes and is in the shape of a half ball. The edges are given bamboo slats for reinforcement while the center is given a wooden block as a handle when used to scoop water in the sea. Seawater extraction is carried out using two timbas, each fitted with a rope to hang it on teku-teku, which is made from a bamboo stick that is cut in half. Teku-teku is also used to carry dry sand flakes if carried with 
two penyuunan. When filling the two penyuunan, or if a break is needed, teku-teku is supported by pemampangan. This supporting tool is made from a wooden rod of about 1.5 meters. The bottom end is pointed so that it is easily stuck into the sand, while the upper end is shaped like a $U$ to support the middle of the teku-teku. Dry sandflakes are then put into belong bias. This sandbox is made of wood and boards about 2.5 meters long, 1 meter wide and 1.5 meters high. One side of the belong bias can be fitted with a wooden board that can be installed and removed (knock down) to facilitate the drainage of sand that has been used to filter seawater. At the bottom is given a hole and a pipe to drain filtered sea water into belong yeh. Belong yeh is made from the base of the trunk of a coconut tree with a length of about 1.5 meters. The center is dredged so that it can hold enough filtered sea water. Each salt farmer usually has 3 belong yeh, each of which is used to collect seawater that has been filtered once, twice and three times. Sea water that has been filtered three times is then transported by means of carrying it using timba to be evaporated in a palung. The transfer of salt water from belong yeh to the timba is done using a dipper called kau. This dipper is made from a half ball shaped coconut shell. Kau is also used to pour salt water from the timba to the palung. This evaporation tool is made from the trunk of a coconut tree which is halved and the center is dredged to a depth of about $3-5 \mathrm{~cm}$. Palungs are arranged in a row in a collapsed position and supported by wood as high as an adult's torso to facilitate the pouring of salt water and salt harvesting. The salt farmers in Kusamba close their palungs with tekep both during the evaporation process and after harvesting. The inside of the palung is kept clean to prevent the evaporated salt water from mixing with dew or rain water and to prevent the salt from mixing with dust. Tekep is made from dried coconut leaves that are lined and tied with wood or bamboo slats and have the same length as a palung. Harvesting salt from the palung is done using a sinduk made from coconut shells, whose shape resembles kau, but smaller in size. The newly harvested salt is temporarily stored in kukusan to be drained over lekeh. Kukusan is made from cone-shaped woven bamboo, while lekeh is made of wood or bamboo pieces [6].

Palung salt-making technology in Kusamba and other places in Buleleng, Karangasem, and Tabanan is a form of adaptation to the environment. The island of Bali is dominated by volcanic soils called regusol and latasol. These soils are rich in nutrients, making them very fertile and suitable for agriculture and plantations. This soil type has coarse grains, tends to be loose, and sensitive to erosion. Such soil texture also allows the sea water to be quickly absorbed and is not favourable to the processing of sea water and its evaporation directly in production land - as is commonly done by salt farmers in Madura, Java, Sulawesi and Sumbawa. The use of the palung is an ingenious strategy to overcome the natural difficulties. Bali also has extensive coconut plantations. In 2019 the total area of coconut plantations in Bali was 71,505 hectares, far more than 35,011 hectares for coffee plantations, 13,927 hectares for cocoa, 15,611 hectares for cloves, and 11,316 hectares for cashew nuts [7]. A similar picture is found in Kusamba Village and Kecamatan Dawan. Ccoconut plantations in Kusamba in 2018 covered 8.7 hectares. At the kecamatan level, coconut plantations covered 821 hectares, smaller than rambutan plantations which covered 1,038 hectares, but larger than other plantations - clove 14.58 hectares, coffee 31 hectares, cocoa 6.8 hectares, and cashew nuts 3 hectares [8]. Coconut plantations also support the sustainability of the traditional salt production in Kusamba. In the description above, many tools in the salt production process in this area are made from parts of a coconut tree. Even so, there are no concerns that this traditional salt production technology will damage the environment. Equipment that requires cutting down many coconut trees, including belong yeh and especially palungs, can last up to 25 years. Salt farmers in general also replace a palung only when it is badly damaged and completely unusable and when do so, they use old and unproductive coconut trees. 
Palung salt from Kusamba contributes to Bali's salt supply along with salt from other traditional salt production centers in Buleleng, Karangasem, and Tabanan. Balinese salt is generally produced using a palung-based solar evaporation method. To increase traditional salt production, the government through the Ministry of Maritime Affairs and Fisheries has introduced the Community Salt Business Empowerment (PUGAR) program for the period of 2011-2015 in salt-producing areas throughout Indonesia. In Bali, this program is implemented by opening new land areas by utilizing potential lands in the coastal areas. The government is also introducing new technologies, namely pumping machines to channel seawater to production land and geosiolators to coat the land surface so that farmers can conduct evaporation directly in crystallization plots. Salt that is produced through evaporation with palungs is called by several terms namely palung salt, sea salt, and organic salt. But the government called it "non-farmed salt" to distinguish it from "farmed salt" produced through evaporation in crystallization plots.

As of the first semester of 2019, Bali's salt production reached 229,249 tons. Salt production centers in Buleleng Regency accounted for 92,755 tons consisting of 89,635 tons of farmed salt and 3,120 tons of non-farmed salt; Karangasem Regency 116,038 tons of nonfarmed salt, Klungkung Regency 18,612 tons of non-farmed salt, and Tabanan Regency 1,844 tons of non-farmed salt [9]. The production data shows that palung salt contributed more to the total salt production in Bali, compared to the contribution of farmed salt, which only came from Buleleng. Palung salt production from Klungkung in the second largest after Karangasem.

The palung salt production process is also efficient, especially in land use compared to farm salt. Palung salt farmers in Buleleng and Karangasem, for example, make use of land that is not too large on the coastline to make a "sari land" which is used to process sea water until it is ready to be evaporated in a palung. The palung salt farmers in Kusamba do not even need to make a sari land because they use black sand beach. Palung can also be arranged in a row on the edge of the sea or other parts of the coastline that are exposed to direct sunlight. This also shows the other side of palung salt production technology which is very dependent on the stability of the coastal environment.

\subsection{Tourism development and zoning areas in Klungkung}

The Nusa Penida region has become one of the strategic tourist destinations. It is in great demand by domestic and foreign tourists. The tourist attraction of this area is mainly from marine tourism include diving, snorkeling, swimming, sailing, fishing, surfing and parasailing. known for its coastal and marine tourism activities. There are several diving spots that become tourist favourite, including Tanjung Penida, Manta Point, SD Point, Kutapang, Toyapakeh, Sental, Buyug, Crystal Bay and Malibu Point. The Nusa Penida region also has a high marine biodiversity. On June 9, 2014 it was designated as a water conservation area called the Nusa Penida Water Park. in which the coral reefs, mangroves, manta rays, sunfish, sun turtles, sea turtles, dolphins, sharks, and whales has become the tourist object [1].

Tourists from Denpasar and the western Bali can reach Nusa Penida via the Port of Sanur. However, for those who coming from the Eastern Bali, the crossing to Nusa Penida will be closer to reach via Port of Tribuana in Kusamba. The crossing from Kusamba to Nusa Penida can be used using traditional boat or speedboat. There is a transportation company that serve speedboat fleet to crossing to Nusa Penida from Kusamba, the company's name is Gangga Express. It provides five speedboats with varying capacities ranging from 50, 55, 76, and the most are 85 passengers. The cruise schedule on every morning (7:00 and 8:00 am) and the afternoon (2:30 pm). In normal weather, the trip from Port of Tribuana to Nusa Penida takes between 30-40 minutes. In the ordinary day, the Gangga Express speedboat fleet serves four trips in the morning and three trips in the afternoon. The trip frequency increases during the 
school holidays in line with the increase of tourists, especially domestic tourists, who visit Nusa Penida. In fact, in the leading up days and after celebrating religious ceremonies, the trip from Tribuana to Nusa Penida is able to surge up to 21 trips per day [10, 11].

In order to support Nusa Penida area as a strategic tourism area, the Klungkung Regency government has sought to improve the accessibility of sea transportation through stabilizing services of the port and passengers. This effort also intended as a strategy for equity and integration of land and islands. The port distribution includes the port of Kutampi Kaler in Klungkung islands and the port of Gunaksa in Klungkung mainland (Dawan District). The two ports serve ferry (ro-ro) both for crossings between the Klungkung mainland and Klungkung islands and between Klungkung and other areas taken through the Badung Strait, such as Karangasem, Padang Bai and Denpasar via the port of Sanur. Meanwhile, passenger ports include Batununggul, Mentigi, Buyuk, and Banjar Nyuh, Jungutbatu, Tanjung Sangyang, and Ceningan ports in Klungkung islands; and Tribuana Kusamba port and Kusamba Village in Klungkung Daratan (both in Dawan District). The passenger ports serve the people's trip both passenger and commodity transportation [12].

In 2018 the Government of the Klungkung Regency also began implementing three port development program which was made a strategic point between the Klungkung mainland and the islands. These three ports are Port of Pesinggahan at Pesinggahan, Dawan District (Klungkung mainland), Port of Sampalan at Batununggul, and Munjul Bias Port in Nusa Ceningan, both in Nusa Penida District Klungkung islands. Therefore, these ports are called the Golden Triangle Port. The Golden Triangle Port construction intended to strengthen connectivity between the mainland and islands and accelerate economic growth in Klungkung Regency [13].

In regards to the construction of the Pesinggahan Port, the government is structuring Pesinggahan beach and the surrounding with Belatung and Kusamba beaches. In addition to the clearing, the arrangement was carried out by rearranging the use of coastal borders to support the port as one of the points in the Golden Triangle Ports. Belatung and Kusamba beaches have been made as tourist attractions, so the land use on both beaches needs to be reorganized, some tourist support facilities should be established such as rest areas and vehicle parking areas. The local community both related to livelihoods and religion activities also need to be regulated, it will be developed in line with tourism sector and does not interfere with tourist comfort. Previously, the Belatung beach has been made for anchoring local fishing boats, while Kusamba beach designed as the salt making area [14].

\subsection{The marginalization of traditional salt farmers}

Based on a study of salt farmers communities in Central Java, Rochwulaningsih saw that the marginalization of salt farming occurred both structurally and exploitatively as a result of competition between the authorities and entrepreneurs over salt as a strategic commodity. At the macro-level, competition between the two forces frequently leads to monopolistic practices and closure of farmers' access to economic resources for the commodity. The marginalization of salt farmers intensified during the colonial era of the Dutch East Indies through the implementation of a wholesaling lease system on Chinese pachter and the monopoly and bureaucratization of salt exploitation, aiming to make salt as an export commodity so that it could contribute to state finances. After independence, the Indonesian government relinquished monopolies and tended to implement a liberalization policy on salt commodities. At the community-level, marginalization of salt farmers occurs through the domination of capitalist modes of production controlled by local petty capitalism through the control of production forces such as land, capital, technology, and markets that 
exploit non-capitalist modes of production that are operationalized by small farmers and workers [15]

The findings have illustrated the processes and forces which influenced the marginalization of salt farmers. Undoubtedly, there is a specific local context which inexplicate through the general pattern of marginalization of salt farmers. Within the concept of tourism development through the expansion of crossing ports as well as people's ports and the Golden Triangle Port, the Klungkung Regency government has emphazied not to conduct evictions and will continue to maintain the existence of palung salt farmers. The government will arrange the location of palung salt in order to make it tidy. Thus, it can add to the tourist attraction on the Belatung and Kusamba beaches. By doing so, palung salt production activities can be integrated into tourism activities [16].

Indeed, the government has fulfilled its promise. We can still find palung salt farmers carrying out production activities at the Kusamba beach until now. Nevertheless, changes are invetable thing. The production area located nearby coastlines increasingly narrow and limited. They can no longer expand sand fields to make flat sand which is used as a medium for processing sea water to be evaporated. The place used to arrange the palung is also increasingly shifting closer to settlements. Indeed, some farmers arrange palung in their yards so that only huts are used to process seawater on the coastline. They are not allowed to carry out production activities at locations closer to the sea because that place has been used to tether boats crossing to Nusa Penida via the Tribuana port.

Beach borders are land along the banks, its length is proportional to the shape and physical condition of the beach, approximately a hundred (100) meters from the highest tide point towards the land. (Law of the Republic of Indonesia No. 1 of 2014). Beach borders are public areas that can be relished by the general public and utilized by the local community. Traditionally, the use by the local community has been going on for generations, the coastline has been claimed as their own. However, in principle coastal borders are owned by the state. Local people only make use of it. They can take advantages from coastal resources both in sea and on land in order to support survival in a way that is not contrary to applicable regulations. In principle, it is the property of the state, in case, the state requires it, the local community must obey it [17].

Admittedly, they have no choices related to the utilization of coastal borders as palung salt cultivation land. Until 2015, when the government implemented the PUGAR program, palung salt farmers in Kusamba can use the coastline as production land freely. Through the program, a salt cooperative in Kusamba has also been formed, namely Amarta Segara and Sarining Segara. Kusamba salt farmers are also the only palung salt community in Bali which are eager to accept geoisolators to overlay their palung. The use of this new equipment make the crops increased, nonetheless, their products are actually difficult for the market. PT Bening, a salt company from Klungkung District which previously consistent to buy Kusamba palung salt, is no longer received their products. This company only buys salts produced with palung technology, particularly without the use of geo-pollinators, plastics or sponges, and is not anodized. This criterion is used strictly in accordance with the demands of its customers, namely hotels and restaurants in Bali, Sumatra and Kalimantan. The use of a geosiolator to overlay the palung seems to have changed the peculiar taste of the salt. Pure palung salt has a savory or slightly sweet taste. Meanwhile, palung salts produced with a geosiolator has a bitter taste [18]. 
Another problem encountered by palung salt farmers in Kusamba is related to iodine content. Their salt have not contain iodine in accordance with the Indonesian National Standard (SNI). The results of laboratory tests conducted by the Office of Maritime Affairs and Fisheries of Klungkung Regency through Sucofindo show that Kusamba palung salt only has an iodine content of $1.6 \mathrm{ppm}$. Based on the provisions in SNI, salt consumption must have an iodine level of 30-80 ppm. The level of iodine which is not in accordance with SNI provisions creates difficulties for Kusamba palung salt farmers in marketing their products [19]. An open opportunity is to sell it to middlemen, by all means, at a price determined by them. The middleman can play around with the price of salt by unilaterally setting and changing it and tends to be low [20]. Following Rochwulaningsih (15], this kind of relationship basically can be categorized as an exploitative relationship, because unilateral pricing by middlemen is deliberately intended to close the access of other parties, in this case palung salt farmers, preventing them from gaining profit from their products.

\section{Conclusion}

Tourism development in Klungkung Regency caused the coastal becoming a contested area by the government and entrepreneurs on the one hand with the local community on the other. The development of community ports and crossings in supporting tourism development and strengthen connectivity between the Klungkung islands and Klungkung mainland makes development-related activities very dominant in coastal areas. This has had an impact on the marginalization of palung salt farmers in Kusamba in the form of restrictions on access to coastal borders as production areas. This salt production activity of the people is also not consistently integrated with tourism activities.

Nevertheless, the marginalization of palung salt farmers in Kusamba is not merely related to changes in the coastal environment as a result of tourism development. It is undeniable that the palung salt production technology in Kusamba, which is very dependent on the existence of a coastal border, also contributes to the process of marginalization in addition to the resilience of this economic enterprise. High dependence on the existence of coastal borders causes this economic activity encounter a lot of pressures when the coastal and coastal environment changes. Production technology innovations through the use of new equipment, especially geoisolators, which were introduced by the government through the PUGAR program are also incompatible because they alter the peculiarities of taste which previously became the superiority of the Kusamba palung salt.

\section{Acknowledgement}

This article is funded by Directorate DRPM DIKTI 2020 under the research Doctoral Dissertation Program entitled Pengetahuan Ekologis Tradisional sebagai Basis Ketahanan Sosial dan Pengembangan Usaha Garam Rakyat di Aceh dan Bali.

\section{References}


1. N.K.A Indrayani \& ND Setiawina. Pengaruh Partisipasi Masyarakat dan Kebijakan Pemerintah terhadap Kesejahteraan Masyarakat melalui Keberlanjutan Pariwisata Nusa Penida. E-Jurnal Ekonomi dan Bisnis Universitas Udayana 7, 4 (2018).

2. Kabupaten Klungkung Dalam Angka 2020. (Semarapura: Badan Pusat Statistik Kabupaten Klungkung, 2020).

3. D.G. Suharto, H.H. Botha, R.H. Haryanti, R.D. Wahyunengseh. Community Marginalization as the Effect of Public Policy in Democratic Governance Era. Bisnis \& Birokrasi: Jurnal Ilmu Administrasi dan Organisasi. International Journal of Administrative Science \& Organization, 25, 3 (2018).

4. P.K. Sanjiwani. Pengaturan Hukum terhadap Privatisasi Sempadan Pantai oleh Pengusaha Pariwisata di Provinsi Bali. Analisis Pariwisata, 16, 1 (2016)

5. Anshori, I.N. Punia, N. Zuryani. Marginalisasi Petani Rumput Laut Pada Masyarakat Pesisir Desa Kampung Toyapakeh Kecamatan Nusa Penida, Klungkung. Jurnal Ilmiah Sosiologi (Sorot) 1, 1 (2017).

6. A.P. Umiarti. Desa Kusamba dan Petani Garam (Universitas Udayana, 2018). https://simdos.unud.ac.id/uploads/file_penelitian_1_dir/6e7592d1f0d5f02b6fbb55ce9d d13286.pdf

7. Provinsi Bali Dalam Angka 2020 (Denpasar: Badan Pusat Statistik Provinsi Bali, 2020).

8. Kecamatan Dawan Dalam Angka 2019 (Semarapura: Badan Pusat Statistik Kabupaten Klungkung, 2019).

https://klungkungkab.bps.go.id/publication/2019/09/26/918a0b17368799965c7d0a21/k ecamatan-dawan-dalam-angka-2019.html

9. Produksi Terbatas Garam Bali Dominan untuk Konsumsi.

https://www.nusabali.com/berita/59651/produksi-terbatas-garam-bali-dominan-untukkonsumsi

10. Pelabuhan Rakyat Tri Buana Kusamba Mulai Menggeliat.

https://www.balipuspanews.com/pelabuhan-rakyat-tri-buana-kusamba-mulaimenggeliat.html

11. Liburan Panjang Usai, Pelabuhan Tribuana Klungkung Dipadati Penumpang. https://radarbali.jawapos.com/read/2018/06/02/78399/liburan-panjang-usai-pelabuhantribuana-klungkung-dipadati-penumpang

12. Peraturan Daerah Kabupaten Klungkung Nomor 1 Tahun 2013 Tentang Rencana Tata Ruang Wilayah Kabupaten Klungkung Tahun 2013-2033.

http://perpustakaan.bappenas.go.id/lontar/file?file=digital/164611-[_Konten_]Konten\%20D1504.pdf

13. Pemkab Klungkung Bangun Pelabuhan Segitiga Emas.

https://mediaindonesia.com/read/detail/142871-pemkab-klungkung-bangun-pelabuhansegitiga-emas

14. Pemkab Klungkung Tata Pantai Pesinggahan.

https://bali.antaranews.com/berita/58136/pemkab-klungkung-tata-pantai-pesinggahan

15. Y. Rochwulaningsih. Marjinalisasi Petani Garam Dan Ekspansi Ekonomi Global: Kasus di Kabupaten Rembang Jawa Tengah. Disertasi pada Sekolah Pascasarjana Institut Pertanian Bogor (2008).

16. Kawasan Pantai Pesinggahan Klungkung Akan Jadi Area Pubklik. https://www.republika.co.id/berita/nasional/daerah/18/01/21/p2wg2n365-kawasanpantai-pesinggahan-klungkung-akan-jadi-area-publik 
17. M.I. Arisaputra. Penguasaan Tanah Pantai dan Wilayah Pesisir di Indonesia. Perspektif Hukum, 15, 1 (2015).

18. Y. Rochwulaningsih, M.p. Utama, S.T. Sulistiyono. Teknologi Garam Palung sebagai Warisan Sejarah Masyarakat Pesisir di Bali. Jurnal Sejarah Citra Lekha, 4, 1 (2019).

19. O. Sinaga, M. Antara, R.K. Dewi. Strategi Pengembangan Usaha Garam Rakyat di Desa Kusamba, Kecamatan Dawan, Kabupaten Klungkung. Agrisocionomics Jurnal Sosial Ekonomi dan Kebijakan Pertanian, 4, 1 (2020).

20. I.P.B. Yogana, I.G.S. Adi, dan N. Parining. Potensi dan Proses Pemberdayaan Petani Garam di Desa Kusamba Kecamatan Dawan Kabupaten Klungkung. Jurnal Agribisnis dan Agrowisata (Journal of Agribusiness and Agritourism), 5, 3 (2016). 